\title{
Pengaruh Gabungan Kelas Antar Tingkatan melalui Metode Role Playing terhadap Hasil Praktek Fungsi Navigasi
}

\author{
Muhammad Abduh'; Riki Wanda Putra, ${ }^{2}$ \\ Politeknik Pelayaran Sumatera Barat \\ *Corresponding Author. E-mail: ${ }^{1}$ mamuk_abduh@yahoo.com; rikiii126@gmail.com
}

\begin{tabular}{|l|l|l|}
\hline Receive: 12/02/2020 & Accepted: 28/02/2021 & Published: 01/03/2021
\end{tabular}

\begin{abstract}
Abstrak
Penelitian ini bertujuan untuk menginvestigasi dan mengetahui pengaruh kelas gabungan antar tingkatan (combined grade) melalui metode role playing terhadap hasil praktek fungsi navigasi bagi taruna/i program studi Nautika angkatan II dan IV di Politeknik Pelayaran Sumatera Barat. Penelitian ini menggunakan metode quasy exsperiment. Data diperoleh melalui Comprehensive Assessment (Function 1. Navigation at The Operational Level) sesuai dengan STCW 78 as Amandement (Regulation A-II/2). Sebanyak 36 taruna/i Program studi Nautika angkatan II dan IVyang di ambil secara acak sebagai sampel penelitian. Hasil analisis data dengan uji-t (t-test) pada post test menunjukkan ada perbedaan yang signifikan antara nilai hasil belajar praktek fungsi navigasi kelompok gabungan antar tingkatan/angkatan (combine grades) dengan kelompok per angkatan melalui metode role playing. Ditunjukkan dengan nilai rata - rata peningkatan tes awal dan tes akhir kelas gabungan yaitu 5,67. Sedangkan, nilai rata - rata peningkatan kelas kontrol angkatan II sebesar 1,25 dannilai rata - rata angkatan IV sebesar 1,00. Dengan demikian,strategi kelompok gabungan antar angkatan (combine grade)menggunakanmetode Role Playing lebih efektif dan efisien dalam peningkatan perolehan hasil belajar praktek dibandingkan pembelajaran praktek menggunakan kelompok homogen (single grade) atau kelompok per angkatan.
\end{abstract}

Katakunci: Kelas Gabungan, Role Playing, dah Hasil Pembelajaran Praktek

\begin{abstract}
This research is aimed to investigate and determine the effectof combined grade class through role playing method for the achievement of simulator practice in learning navigation function at Politeknik Pelayaran Sumatera Barat. The quasy experiment methodwas used for doing this study. The data were collected through Comprehensive Assessment (Function 1. Navigation at The Operational Level) in accordance with STCW 78 as Amandement (Regulation A-II / 2). Meanwhile, 36 Nautical cadets from batch II and IV were randomly chosen as the sample. The results of data analysis with the t-test in the post test showed that there was a significant difference between the learning achievementof combined gradeand groups per grade. The mean value of pre-test and posttest in the combined gradewas 5.67. While, the mean value of class grade II was 1.25 and 1.00 was the mean of class grade IV. It implied that the combined grade group strategy by using the role playing method is more effective and efficient in increasing the achievement of simulator practice compared to using homogeneous groups (single batch) or groups per grade.
\end{abstract}

Keywords:Combined grade, Role Playing and simulator achievement 


\section{PENDAHULUAN}

Pendidikan dipandang sebagai instrumen sosial untuk pembangunan sumber daya manusia dan membangun kapital manusia serta meningkatkan produktivitas nasional. Pendidikan memberikan kontribusi yang sangat penting, terutama di bidang pelayaran. Sebagai negara kepulauan terbesar di dunia, Indonesia memiliki potensi untuk meningkatkan pertumbuhan ekonomi melalui bidang pelayaran.Olehkarena itu, peningkatan sumber daya manusia yang berkualitas, memiliki kompetensi, berkarakter dan profesional di bidang pelayaran terus ditingkatkan melalui pendidikan vokasi dibawah naungan Kementerian Perhubungan.

Sejak ditanda-tangani Surat Keputusan Bersama (SKB) antara Menteri Perhubungan, Menteri Pendidikan dan Menteri Tenaga Kerja dan Transmigrasi tentang Standar Mutu Kepelautan Indonesia Tahun 2003 dalam rangka menghadapi tantangan diberlakukannya Standard Training, Certification and Watchkeeping for Seafarers (STCW) 1978 dan amandemennya, makapendidikan dan pelatihan bagi pelaut berkembang sangat pesat. Banyaknya pembangunan Pendidikan Tinggi dibidang Pelayaran diseluruh Indonesia menjadi salah bukti perkembangan pendidikan vokasi bidang pelayaran. Artinya bahwa penggabungan antara sistem Pendidikan Tinggi Nasional dan StandardInternasional ini melahirkan institusi unggul yang terakreditasi dan dilengkapi dengan Simulator serta Laboratorium yang canggih.

Simulator merupakan sebuah peralatan yang dirancang untuk mewakili keadaan-keadaan sesungguhnya. Hal itu sejalan dengan ketentuan Internasional yang tertuang dalam Seafarers' Training, Certification, and Watchkeeping (STCW) Code 1978 beserta amandemennya, khususnya pada Section A-I/12 tentang standar penggunaan simulator sebagai sarana pembelajaran dan pengujian. Namun, terlepas dari sekedar sebuah kewajiban memenuhi ketentuan, tentu PoliteknikPelayaran sebagai pendidikan vokasi memiliki kewajiban untuk mencetak lulusan yang siap diserap oleh dunia kerja. Dengan demikian, pengetahuan dan keterampilan yang dimiliki lulusan harus sesuai dengan kebutuhan dunia kerja. Salman (2013) dalam disertasinya di World Maritime University menyatakan pentingnya penggunakan simulator untuk meningkatkan kompetensi para Nakhoda dan perwira jaga. Adapun kompetensi yang diharuskan bagi seorang lulusan Politeknik Pelayaran, dalam hal ini dari program studi Nautika, dikelompokkan ke dalam empat fungsi yaitunavigation, cargo handling and stowage, controlling the operation of the ship and care for persons on board, dan radio communications.

Pada pembelajaran fungsi navigasi (navigation) di simulator anjungan (bridge simulator), taruna/i diharapkan benar benar mampu menghadapi kenyataan yang sesuai dengan situasi sebenarnya baik dari kecakapan bersikap dan bertindak. Pembelajaran tersebut merupakan suatu proses peniruan dari sesuatu yang nyata beserta keadaan sekelilingnya (state of affairs). Hontvedt (2014) dalam thesis doktoralnya di University of Oslo memaparkan hasil penelitian yang menunjukkan bahwa simulator sangat berpotensi untuk menjembatani antara pendidikan dan dunia kerja. Aksi melakukan simulasi ini secara umum menggambarkan sifat-sifat karakteristik 
kunci dari kelakuan sistem fisik atau sistem yang abstrak tertentu. Artinya bahwapembelajaran Fungsi Navigasi pada media bridge simulator sangat menitikberatkan proses pelaksanaan pembelajaran layaknya keadaan yang sebenarnya. Perkovic dkk (2013) menyatakan bahwa penggunaan simulasi maritim yang terintegrasi dapat digunakan untuk menghadirkan keadaan nyata yang mungkin terjadi di laut kedalam proses pembelajaran.Olehkarena itu, taruna/i diberikan pembelajaran dan pemahaman bahwa proses operasional kapal yang dilakukan harus benar-benar sesuai dengan aturan dan standar operasional yang berlaku. Kemudian, dalam pembelajaran ini para taruna/i dituntut untuk berperan maksimal sesuai dengan posisi, tingkat dan tanggungjawabnya masing-masing seperti sebagai seorang Nahkoda (Manajeman Level), Mualim (Operational Level) atau bahkan hanya seorang Juri Mudi (Supporting Level).

Berdasarkan hasil observasi dan pengalaman yang peneliti lakukan mengenai proses pembelajaran Fungsi Navigasi bridge simulatordiPoliteknik Pelayaran Sumatera Barat, dosen melaksanakan pembelajaran praktek menggunakan metode konvensional dengan kelompok yang homogen. Setiap kelas yang mendapatkan pelajaran praktek di simulator dibuat secara kelompok dengan teman sekelasnya. Dengan demikian, taruna/i tidak berperan maksimal dan tidak serius dalam menjalankan perannya sebagai nahkoda, mualim atau juri mudi pada saat pembelajaran fungsi navigasi di bridge simulator. Sehingga, pembelajaran fungsi navigasi di simulatorterkesan monoton, tidak menarik,taruna/i kurang bersemangat dan cenderung tidak merasa tertantang dengan pembelajaran tersebut. Salah satu penyebab permasalahan itu adalah kurangnya penelitian pembelajaran simulator.Senada dengan argumen yang di kemukan Sellberg (2017) bahwa penelitian terkait pelatihan maritim berbasis simulator masih sangat sedikit atau terbatas.Terkait dengan persoalan tersebut, perlu adanya suatu tindakan yang dilakukan oleh peneliti. Tindakan yang dapat dilakukan adalah melakukan inovasi proses pembelajaran dengan menggunakan metode yang tepat. Salah satu metode pembelajaran yang memungkinkan dapat digunakan adalah metode simulasi bermain peran (role playing) melalui kelasgabungan antar tingkatan (Combined Grade).

Melalui metode tersebut, dosen mencoba mengekspresikan hubunganhubungan antar taruna/i yang terdiri dari beberapa level tingkatan(angkatan) di gabung menjadi satu grup/kelompok belajar. Yaitu dengan cara memperagakan berbagai tingkat jabatan di kapal, bekerja sama dan mendiskusikannya, sehingga secara bersama-sama dosen dapat mengeksplorasi perasaan, sikap, nilai dan berbagai strategi pemecahan masalah. Dalam penerapannya, metode ini perlu didukung oleh beberapa hal penting yang memberi manfaat untuk mencapai tujuan pelajaran yaitu penggunaan peralatan permainan peran seperti gambar-gambar yang dibuat menarik, menciptakan suasana yang menyenangkan, serta lembar evaluasi yang dapat menjadi feed back bagi pencapaian tujuan pembelajaran (Sugiharti, 2009). Pelaksanaan kelasgabunganantar tingkatan/angkatan(Combined Grade) melalui metode role playing mengedepankan keterlibatan taruna/i dalam melakukan kegiatan belajar, 
terutama dalam bentuk kerja sama dan partisipasi dalam kelompok yang tergambardalam sebuah interaksi sosial di antara taruna/i maupun antar kelompok.

Melalui metoderole playingtaruna/i dituntut dapat menjadi pribadi yang imajinatif, mempunyai prakarsa, mempunyai minat luas, mandiri dalam berfikir, ingin tahu, penuh energi dan percaya diri. Teknik gabungan melalui metode Role playing diharapkan memberikan suasana yang menyenangkan meskipun dalam situasi taruna/i digabung dengan berbagaitingkatan level/angkatan. Taruna/i diharapkan dapat terlibat secara aktif dalam pembelajaran sehingga taruna/i lebih antusias dalam mengikuti pelajaran dan lebih memahami materi pelajaran sehingga hasil belajar meningkat. Berdasarkan latar belakang yang telah diuraikan, peneliti ingin membuktikanbahwa

penerapanteknikkelasgabunganantar tingkatan/angkatan(Combined Grade) melalui metode role playing berpengaruh terhadap hasil belajar fungsi navigasi pada taruna/i Program Studi Nautika Angkatan II dan IV di Politeknik Pelayaran Sumatera Barat.

\section{Rumusan Masalah}

Berdasarkan identifikasi masalah di atas, maka peneliti dapat merumuskan masalah sebagai berikut: Bagaimanakah pengaruh kelasgabunganantartingkatan/angkatan $(\mathrm{Co}$ mbined Grade) melalui metode role playing terhadap hasil belajar praktek Fungsi Navigasi pada taruna/i Program Studi Nautika Angkatan II dan IV di Politeknik Pelayaran Sumatera Barat?

\section{Tujuan Penelitian}

Penelitian ini dilaksanakan dengan tujuan untuk membuktikan pengaruh gabungan kelas antar tingkatan/angkatan(Combined
Grade) melalui metode role playing terhadap hasil belajar praktek Fungsi Navigasi pada taruna/i program Studi Nautika Angkatan II dan IVdi Politeknik Pelayaran Sumatera Barat.

\section{METODOLOGI PENELITIAN}

\section{Metode Penelitian}

Metode yang digunakan dalam penelitian ini dalah metode eksperimen. Menurut Sugiyono (2012), "metode eksperimen dapat diartikan sebagai metode penelitian yang digunakan untuk mencari pengaruh perlakuan tertentu terhadap yang lain dalam kondisi yang terkendali". dikarenakan penelitian ini bukan penelitian eksperimen murni maka metode penelitian yang digunakan dengan menggunakan bentuk penelitian Quasy Experimental (Sugiyono, 2016:109).

\section{Populasi dan Sampel}

Populasi dalam penelitian ini adalah seluruh Taruna/i program studi Nautika Angkatan II dan IV Politeknik Pelayaran Sumatera Barat yang yang terdiri dari tiga (3) kelas angkatan II dan lima (5) kelas angkatan IV. Setiap kelas berjumlah 20 orang taruna/i, sehingga jumlah total Populasi yang digunakan adalah 160 orang taruna/i.

Sampel menurut Syaodih (2010) adalah "kelompok kecil yang secara nyata kita teliti dan tarik kesimpulan disebut dengan sampel". Sampel dalam penelitian ini diambil secara acak dengan menggunakan teknik Simple Random Sampling. Sebanyak 6 taruna/i angakatan II dan 6 taruna/i angkatan IV yang di pilih secara acak menjadi sampel sebagai kelas eksperimen yaitu kelas gabungan. Dengan kata lain, jumlah total sampel pada kelas eksperimen (kelas gabungan) adalah 12 taruna/i yang berasal dari angkatan II dan IV. Kemudian, dalam penelitian ini terdapat dua kelas kontrol yaitu kelas kontrol angkatan II dan angkatan IV. 
Masing - masing kelas kontrol memiliki 12 taruna/i dari tiap - tiap angkatan sebagai sampel penelitian ini.

\section{Instrumen Penelitian}

Instrumen penelitian yang digunakan dalam penelitian ini adalah COMPREHENSIVE ASSESSMENT (Function 1. Navigation at The Operational Level) sesuai dengan STCW 78 as Amandement (Regulation A-II/2). Tes ini merupakan bentuk penilaian terhadap kemampuan praktek Fungsi Navigasi di bridge Simulator yang dibuat sesuai dengan kompetensi/jabatan yang ada diatas kapal.

\section{Teknik Analisis Data}

Teknik analisis data dalam penelitian ini menggunakan analisis varian (Anava). Analisis Varians (ANAVA) adalah teknik analisis statistik yang dikembangkan dan diperkenalkan pertama kali oleh Ronald. A Fisher (Kennedy \& Bush, 1985) dalam sudjana (2002). Dalam penelitian ini digunakan jenis Anova satu arah. Prinsip pengujiannya adalah menganalisis variabilitas atau keragaman data menjadi dua sumber variasi, yaitu variasi dalam kelompok (within) dan variasi antar kelompok (between).

\section{HASIL DAN PEMBAHASAN}

Penelitian ini merupakan quasi eksperimental design yang menggunakan tiga bentuk kelompok, yaitu kelompok gabungan antar tingkatan (combine grades) dan kelompok non gabungan yaitu kelompok Angkatan II dan Angkatan IV. Dalam pelaksanaannya, peneliti menggunakan materi yang sama (fungsi navigasi) dan metode yang sama (role playing)pada semua kelompok. Penelitian ini dilaksanakan pada bulan Oktober dan November 2020. Pelaksanaan penelitian meliputi kegiatan familirisasi alat, pre test, pelaksanaan metode Role Playing dan post test.Dari penelitian ini di dapatkan hasil pre test dan post testdari semua kelompok penelitian yang di uraikan sebagai berikut:

1. Data Hasil Pre Test dan Pos Test KelompokAngkatan II

Data hasil Pre Test dan Post Test kelompokangkatan II di gambarkan dalam grafik di bawah ini.

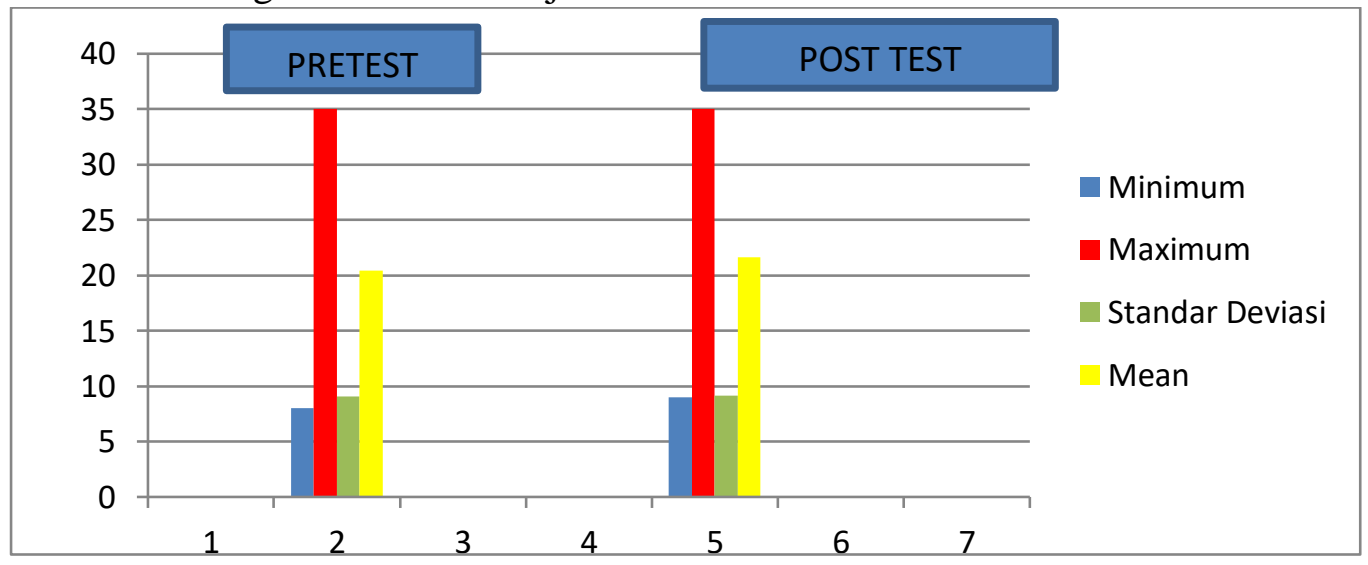

Gambar 1 : Diagram Grafik Skor Pre Test Dan Post TestAssesment Praktek Navigasi Kelompok Angkatan II

Grafik diatas menunjukkan bahwa skor minimum yang diperoleh oleh taruna/i untuk nilai pre testadalah 8 dan skor minimum post testtaruna/i adalah 9.Sedangkan, skor maksimum yang diperoleh dari pre test dan post test kelompok angkatan II adalah sama yaitu 35. Standar deviasi untuk nilai pre test yaitu 9,08 dan untuk nilai post testadalah 9,18 , sementara itu nilai rata-rata pre test jumlah persentasenya sebesar 20,42\% dan 
skor nilai rata-rata post test jumlah persentasenya sebesar 21,67\%.
Grafik dibawah ini menunjukkan hasil pre test dan post test taruna/i kelompok angkatan IV.

2. Data Hasil Pre Test dan Pos Test KelompokAngkatan IV

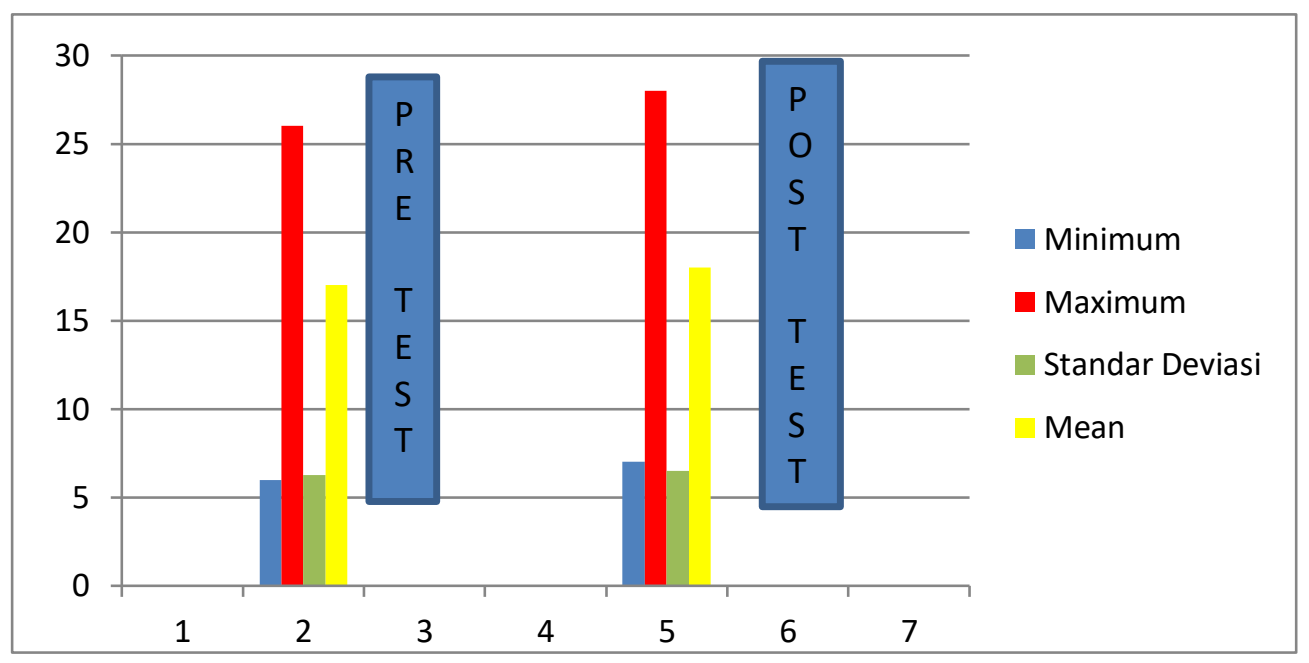

Gambar 2 : Diagram Grafik Skor Pre Test dan Pos TestAssesment Praktek Navigasi Kelompok Angkatan IV

Diagram grafik skor pre test dan post test kelompok angkatan IV menunjukkan pemerolehan skor minimum untuk nilai pre test adalah 6 dan nilai minimum post test adalah 7. Sedangkan, skor maksimum pre test yaitu 26 dan skor maksimum post test yaitu 28. Standar deviasi untuk nilai pre testkelompok angkatan IV adalah 6,27 dan standar deviasi post testkelompok angkatan IV yaitu 6,52. Kemudian, nilai rata-rata pre testpersentasenya adalah $17 \%$ dan skor nilai rata-rata post testpersentasenya $18 \%$.

3. Data Hasil Pre Test dan Pos Test KelompokGabungan Angkatan II dan IV (Combine Grades)

Berikut ini adalah grafik hasil pre test dan post test taruna/i dari kelompok gabungan

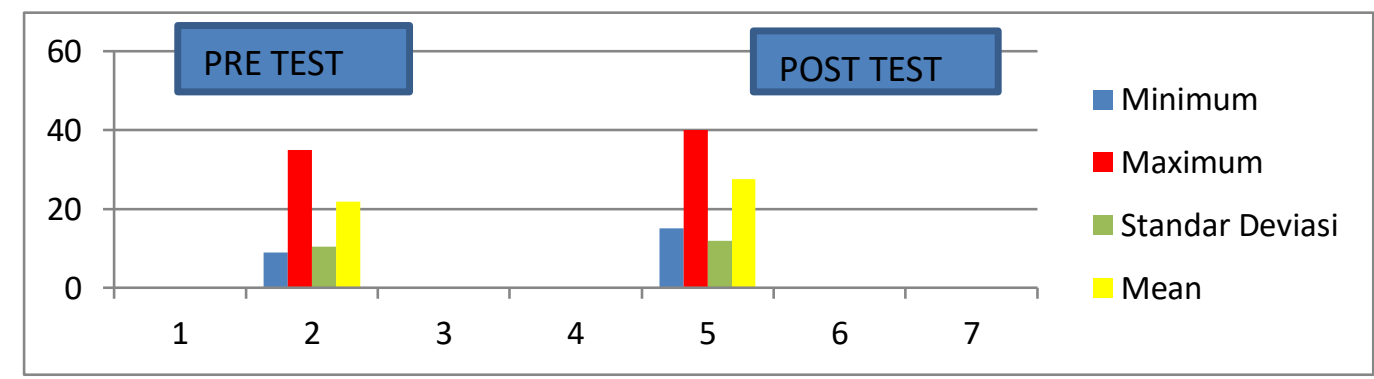

Gambar 3 : Diagram Grafik Skor Pre Test dan Post TestAssesment Praktek Navigasi Kelompok Gabungan Antar Tingkatan (combine grades)

Diagram grafik skor pre test dan posttestdi atas menggambarkan bahwa skor minimum untuk nilai pre testadalah 9 dan skor minimum untuk nilai post testadalah15. Sedangkan, skor maksimum nilai pre testyaitu 35 dan skor maksimum nilai post 
Jurnal Edumaspul, 5 (1), Year 2021- 45

(Muhammad Abduh; Riki Wanda Putra)

testyaitu 40, standar deviasi nilai pre testadalah 10,39 dan post testadalah 11,89.Disamping itu, nilai rata-rata pre test jumlah persentasenya adalah $21,83 \%$ dan nilai rata-rata post test jumlah persentasenya mencapai $27,50 \%$.
4. Data Peningkatan Hasil Pre Test dan Pos Test Untuk Ketiga Kelompok Angkatan II, Angkatan IV dan Kelompok Gabungan Antar Tingkatan (Combine Grade)

Data Peningkatan ini diambil dari hasil Pre Test dan Post Test yang diberikan pada seluruh kelompok.

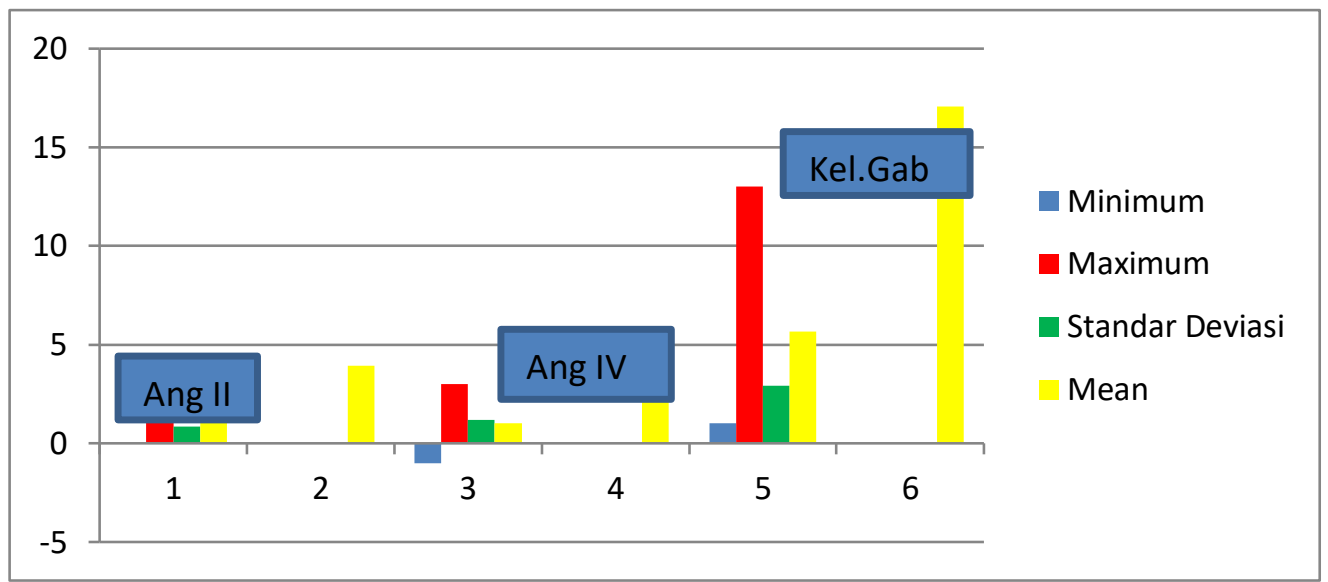

Gambar 4 : Diagram Grafik Skor Peningkatan Pre Test dan Pos TestAssesment Praktek Navigasi Kelompok Angkatan II dan IV dan Kelompok Gabungan Antar Tingkatan (Combine Grade)

Dari grafik gambar 4 diperoleh skor minimum untuk nilai peningkatan dari kelompok Angkatan II adalah 0 dan nilai maksimumnya adalah 2, kemudian skor minimum untuk nilai peningkatan kelompok Angkatan IV yaitu -1 dan nilai maksimum peningkatan angkatan IV yaitu 3, sedangkan skor minimum untuk nilai peningkatan kelompok gabungan Angkatan II dan IV (combine grades) adalah 1 dan nilai maksimum peningkatan kelompok gabungan adalah 13. Standar deviasi untuk nilai peningkatan kelompok Angkatan II sebesar 0,87 dan standar deviasi untuk nilai

\section{Analisis Data}

1. Uji Homogenitas dan Normalitas

\section{UJI HOMOGENITAS== MENGGUNAKAN PERHITUNGAN UJI F-HARTLEY}

\begin{tabular}{|c|c|c|c|}
\hline KELOMPOK & $\mathrm{n}$ & $\mathrm{db}$ & $\mathrm{s} 2$ \\
\hline $\mathrm{A} 1$ & 12 & 11 & 0,574 \\
\hline $\mathrm{A} 1$ & 12 & 11 & $\mathbf{0 , 9 0 2}$ \\
\hline
\end{tabular}




\begin{tabular}{|c|c|c|c|}
\hline A3 & 12 & 11 & $\mathbf{0 , 9 5 4}$ \\
\hline JUMLAH & 36 & 33 & 0,965 \\
\hline
\end{tabular}

KETERANGAN : VARIAN SAMPEL

$\mathrm{F}$ maks $=$

$\frac{\text { varian terbesar }}{\text { varian terkecil }}=\frac{0,902}{0,954}=\mathbf{0 , 9 5}$

2. Hitung Jumlah Kuadrat (JK) untuk sumber beberapa variasi kelompok, yaitu: Total (T), Antar (A), dan Dalam (D)

Tabel 1: Perhitungan (JK) untuk sumber beberapa variasi, yaitu: Total (T), Antar (A), dan Dalam (D)

\begin{tabular}{|l|l|l|l|l|}
\hline $\mathrm{JK}(\mathrm{T})=$ & $\sum \mathrm{Y}_{\mathrm{t}}^{2}-\left(\sum \mathrm{Y}_{\mathrm{t}}\right)^{2} / \mathrm{n}_{\mathrm{t}}$ & $=535-(95)^{2} / 36=$ & $\mathbf{2 8 4 , 3 1}$ \\
\hline $\mathrm{JK}(\mathrm{A})=\mid \sum \sum\left(\mathrm{Y}_{\mathrm{i}}\right)^{2} / \mathrm{ni}-\sum\left(\mathrm{Y}_{\mathrm{t}}\right)^{2}$ & $=\left(15^{2} / 12\right)+\left(12^{2} / 12\right)+\left(68^{2} / 12\right)-\left(95^{2} / 36\right)=$ & $\mathbf{1 6 5 , 3 9}$ \\
\hline $\mathrm{JK}(\mathrm{D})=\mid \sum\left\{\sum \mathrm{Y}_{\mathrm{i}}^{2}-\left(\sum \mathrm{Y}_{\mathrm{i}}\right)^{2} / \mathrm{n}_{\mathrm{i}}\right\}$ & $=\sum \mathrm{y}_{\mathrm{i}}^{2}$ & $\mathbf{1 1 8 , 9 2}$ \\
\hline
\end{tabular}

Keterangan :

1. $\mathrm{JK}(\mathrm{T})$ : Jumlah Kuadrat Total (Ketiga Kelompok) $=\mathbf{2 8 4 , 3 1}$

2. $\operatorname{JK}(\mathrm{A})$ : Jumlah Kuadrat Antar (Ketiga Kelompok) $=\mathbf{1 6 5 , 3 9}$

3. JK(D) : Jumlah Kuadrat Dalam (Ketiga Kelompok) = 118,92

3. Menentukan derajat bebas ( $\mathrm{Db})$ masing-masing sumber variasi:

$$
\begin{array}{l|l|l}
\mathrm{Db}(\mathrm{T})=36-1 & \mathrm{Db}(\mathrm{A})=3-1 & \mathrm{Db}(\mathrm{D})=36-3
\end{array}
$$

4. Menentukan Rata-rata Jumlah Kuadrat (RJK):

\begin{tabular}{|l|l|}
\hline $\mathrm{RJK}(\mathrm{A})=\mathrm{JK}(\mathrm{A}) / \mathrm{db}(\mathrm{A})=165,39 / 2=$ & 82,69 \\
\hline $\mathrm{RJK}(\mathrm{D})=\mathrm{JK}(\mathrm{D}) / \mathrm{db}(\mathrm{D})=118,9 / 33=$ & 3,604 \\
\hline
\end{tabular}

5. Menghitung Fo :

$$
\mathrm{Fo}=\operatorname{RJK}(\mathrm{A}) / \mathrm{RJK}(\mathrm{D})=82,69 / 3,60
$$

6. Menghitung ukuran efek (effect Size) $\eta 2$ :

\begin{tabular}{|l|l|l|l|l|l|}
\hline $\begin{array}{l}\text { Sumber } \\
\text { Variasi }\end{array}$ & JK & db & RJK & Fo & Ft $\alpha(0,05)$ \\
\hline Antar & 165,39 & 2 & 82,7 & $\mathbf{2 2 , 9 5}$ & $\mathbf{3 , 2 9}$ \\
\hline
\end{tabular}




\begin{tabular}{|l|l|l|l|l|} 
Dalam & 118,92 & 33 & 3,6 & \\
Total & 284,31 & 35 & & \\
\hline
\end{tabular}

Tabel 2: Annova 1 Jalur

Kesimpulan :

Fo $=22,95>$ Ftab $=3,29$ atau Ho ditolak dan Ha diterima. Hal ini berarti terdapat perbedaan di antara ketiga kelompok perlakuan. Disini berarti data yang didistribusikan adalah normal.

7. Uji Lanjut (post hoc test). Untuk menguji rata-rata di antara ketiga kelompok perlakuan digunakan uji-t dari Dunnet :

\begin{tabular}{|c|r|r|}
\hline $\mathrm{t}_{\mathrm{o}}(\mathrm{A} 3-\mathrm{A} 1)=$ & $\frac{\overline{\mathrm{Y}} 1-\overline{\mathrm{Y}} 2}{\sqrt{R J K(D)\left(\frac{1}{n 1}+\frac{1}{n 2}\right)}}$ & $\frac{5,67-1,25}{\sqrt{3,604\left(\frac{1}{12}+\frac{1}{12}\right)}}=\mathbf{5 , 7 0}$
\end{tabular}

\begin{tabular}{|l|r|r|}
\hline $\mathrm{t}_{\mathrm{o}}(\mathrm{A} 3-\mathrm{A} 2)=$ & $\frac{\overline{\mathrm{Y}} 1-\overline{\mathrm{Y}} 3}{\sqrt{R J K(D)\left(\frac{1}{n 1}+\frac{1}{n 2}\right)}}$ & $\frac{5,67-1,00}{\sqrt{3,604\left(\frac{1}{12}+\frac{1}{12}\right)}}$
\end{tabular}$=\mathbf{6 , 0 3}$

\begin{tabular}{|c|c|c|c|c|}
\hline & $\bar{Y} 1-\bar{Y} 3=$ & $1,25-1,00$ & & \\
\hline$t_{o}(A 1-A 2)=$ & $\sqrt{R J K(D)}\left(\frac{1}{n 1}+\frac{1}{n 2}\right)$ & $\sqrt{3,604\left(\frac{1}{12}+\frac{1}{12}\right)}$ & $=$ & $\mathbf{0 , 3 2}$ \\
\hline
\end{tabular}

Analisis Perhitungan nilai t tabel adalah sebagai berikut :

$(\mathrm{N}-3)=36-3=33$

$\mathrm{t}_{\text {tabel }}=\mathrm{t}_{0,05(33)}=\mathbf{1 , 6 8}$

Keterangan : $\mathrm{N}=$ jumlah sampel

8. Kesimpulan Hasil Pengujian Hipotesis :

a. to $(\mathrm{A} 3-\mathrm{A} 1)=5,70>$ ttabel $=1,68$ Ho ditolak. Dengan demikian Hasil Praktek Fungsi Navigasi kelompok A3 (combine grades) lebih tinggi daripada kelompok A1 (Angkatan II). 
b. to $(\mathrm{A} 3-\mathrm{A} 2)=6,03>$ ttabel $=1,68$ Ho ditolak. Dengan demikian Hasil Praktek Fungsi Navigasi kelompok A3 (combine grades) lebih tinggi daripada kelompok A2 (Angkatan IV).

c. to $(\mathrm{A} 1-\mathrm{A} 2)=0,32<$ ttabel $=1,68$ Ho diterima. Dengan demikian tidak terdapat perbedaan Hasil Praktek Fungsi Navigasi antara kelompok A1 (Angkatan II) dan kelompok A2 (Angkatan IV).

\section{Pembahasan}

Berdasarkan data yang diperoleh dan hasil analisis data menunjukkan bahwa terdapat perbedaan peningkatanhasil belajar praktek antara kelompok Angkatan II, kelompok Angkatan IV dan Kelompok kelas gabungan (combine grades). Hal tersebut dapat di lihat dari nilai rata - rata peningkatan tes awal dan tes akhir kelas gabungan yaitu 5,67. Sedangkan, kelas kontrol angkatan IImendapatkan nilai rata rata peningkatan sebesar 1,25 dan angkatan IV mendapatkan nilai rata - rata peningkatan sebesar 1,00. Kemudian, kelompok gabungan antar tingkatan/angkatan (combine grades) mendapatkan nilai rata-rata sebesar $17,05 \%$ sedangkan kelompok per angkatan yaitu kelompok angkatan II mendapatkan nilai rata - rata sebesar 3,94\% dan kelompok angkatan IV mendapatkan nilai rata-rata sebesar 2,69\%. Hasil analisis data dengan uji-t (t-test) pada post test atau tes akhir menunjukkan ada perbedaan yang signifikan antara nilai hasil belajar praktek fungsi navigasi kelompok gabungan antar tingkatan/angkatan(combine grades)dengan kelompok per angkatan melalui metode role playing. Hal tersebut diperkuat dengan nilai persentase rata-rata yang jauh berbeda. Dengan demikian dapat dinyatakan bahwa ada perbedaan hasil yang signifikan antara kelompok gabungan antar angkatan (combine grades) dan kelompok per angkatan.
Hal ini dikarenakan teknik gabungan antar angkatan melalui metode pembelajaran role playing dalam pembelajaran praktek fungsi navigasi sangat efektif sehingga mendapatkan hasil yang maksimal. Sedangkan pembelajaran yang diterima oleh kelompok non gabungan antar angkatan atau kelompok per angkatan merupakan pembelajaran yang biasa dilakukan oleh dosen yaitu membagi kelompok berdasarkan angkatan yang sama.Hasil pengamatan pada kelompok

kelompokperangkatanmenunjukkan bahwa dosen lebih mudah dalam mengkondisikan taruna/i untuk melaksanakan materi skenario praktek yang telah disediakan, tetapitaruna/i kurang antusias dalam mengikuti proses pembelajaran serta tidak terlihat berjalannya fungsi hiraki jabatan diatas kapal sesuai tanggungjawab dalam pelaksanaan praktek fungsi navigasi. Perhatian taruna/i terhadap materi hanya pada menit-menit awal pembelajaran saja. Seiring proses kegiatan praktek berjalan perhatian taruna/i terhadap pembelajaran berkurang dan pelaksanakan praktek tidak maksimal sehingga hasil yang dicapai menjadi kurang maksimal dan kurang efektif.

Sedangkan pembelajaran pada kelompok gabungan antarangkatan, dalam hal ini, gabungan dari angkatan II dan angkatan IV melalui metode role playingberjalan dengan baik. Dimana taruna/i sangat antusias dalam mengikuti pembelajaran praktek fungsi navigasi dengan menggunakan metode role playing. 
Disamping itu, pelaksanakan pembelajaran praktek dengan menggunakan metode role playingsangat efektifsehingga dapat mencapai hasil yang maksimal. Sebagaimana yang disampaikan Gangel, K. (1986) bahwa metode Role Playing atau bermain peran membantu siswa menemukan jati diri di dunia sosial dan memecahkan permasalahan yang dihadapi. Metode ini menarik bagi taruna/i karena proses pembelajaran dilakukan seperti sebuah permainan. Role playing sebagaimana yang disampaikan oleh Aswan (2006) dapat menjadikan siswa lebih memahami isi bahan dalam memainkan peran dan hirarki diatas kapal.

Kelompok taruna/i pada kelas gabungan antar tingkatan/angkatan(combine grades) lebih memahami isi dari bahan Berdasarkan hasil penelitian dan pembahasan, terdapat pengaruh yang signifikan pada hasil belajar praktek fungsi navigasi taruna/i Politeknik Pelayaran Sumatera Barat pada kelompok kelas eksperimen yaitu kelompok gabungan antar tingkatan (combine grades)yang terdiri dari angkatan II dan angkatan IV. Hal tersebut dapat ditunjukkan dariperbedaan peningkatan hasil belajar masing-masing kelompok. Dari hasil penghitungan uji-t (t-test) serta dari perbedaan rata-rata nilai yang diperoleh, maka dapat disimpulkan bahwa pelaksanaan praktek dengan kelompok gabungan antar tingkatan (combine grades) melalui metode Role Playing memberikan pengaruh terhadap hasil belajar praktek fungsi navigasi taruna/i Politeknik Pelayaran Sumatera Barat. Strategi kelompok gabungan antar angkatan (combine grade)menggunakanmetode Role Playing pada kelas eksperimen akan lebih lebih efektif dan efisien dalam peningkatan skenario praktek yang diajarkan karena siswa memerankan fungsi secara hirarki jabatan dan tanggungjawab diatas kapal secara baik. Sehingga hasil belajar praktek fungsi navigasi taruna/i kelas eksperimen gabungan antar tingkatan (combine grades) menggunakan metode Role Playing menjadi lebih baik karena menjadikan taruna/i lebih aktif dan memberikan pengalaman yang berkesan bagi mereka. Hal tersebut menunjukkan bahwa pengaruh kelas gabungan antar tingkatan/angkatan(combine grades) menggunakan metode Role Playing berpengaruh terhadap hasil belajar praktek fungsi navigasi taruna/i Politeknik Pelayaran Sumatera Barat.

\section{KESIMPULAN DAN SARAN \\ Kesimpulan}

perolehan hasil belajar praktek dibandingkan pembelajaran praktek menggunakan kelompok homogen (single grade) atau kelompok per angkatan.

\section{Saran}

Dosen/Instruktur disarankan untuk menerapkan kelompok gabungan antar tingkatan(combine grades) dengan menggunakan metode Role Playing. Kemudian, penyelenggara kependidikan dapat memfasilitasi dengan merubah pola penjadwalan pembelajaran praktek taruna tingkat I dan tingkat III pada hari dan jam yang sama sehingga dapat bergabung untuk membentuk role playingseperti di kapal dengan adanya atasan (senior officers) dan bawahannya (officers).

\section{DAFTAR PUSTAKA}

Aswan , Zain, Bahri syamsul, Djamarah .2006. Strategi Belajar Mengajar. Jakarta : Penerbit PT. Rineka Cipta

Gangel, K. 1986. Teaching Through Role Playing 24 Ways To Improve Your Teaching. Tersedia pada 
http://www.scribd.com . Diakses pada tanggal 5 Oktober 2020

Hontvedt, M. 2014. Simulations in Maritime Training, A Video Study of the Socio-Technical Organisation of Ship Simulator Training, Oslo, Department of Education - Faculty of Educational Sciences.

Perkovic, M., Harsch R., Suban V., Vidmar P., Nemec D., Muellenhoff O., \& Delgado L.2013. 'The Use of Integrated Maritime Simulation for Education in Real Time', ResearchGate/ Pub.228912986, p. 461 $-478$.

Salman, A.K.M.D.W. 2013. 'The Importance of Using Ship Bridge Simulation Training to Enhance the Competency of Masters and Watchofficers : A Case Study of the Iraqi Dredging Fleet', The Maritime Commons : Digital Respository of the World Maritime University, Sweden: WMU.

Sellberg, C. 2017. 'Simulators in Bridge Operation Training and Assessment :
A Systematic Review and Qualitative Synthesis', WMU J Marit Affairs, no. 16 , p. $247-263$.

Sudjana.2002.Metoda Statistika.Tarsito : Bandung.

Sugiharti, G. 2009. Jurnal Online : Penerapan Metode Bermain Peran PadaPembelajaran Struktur Atom Di Kelas X MAN 1 Medan Tahun Pelajaran 2008/2009. Jurnal Pendidikan Matematika dan Sains 4(1) : 77-81

Sugiyono.2016. Metode Penelitian Kuantitatif, Kualitatif dan $R \& D$. Bandung: PT Alfabet.

Sugiyono.2012. Metode Penelitian Kuantitatif Kualitatif dan $R \& B$. Bandung: Alfabeta

Syaodih Sukmadinata. 2010. Metode Penelitian Pendidikan. Bandung: PT Remaja Rosdakarya. 